\title{
THE INFLUENCE OF CORPORATE FINANCIAL PERFORMANCE ON SHARE RETURN
}

\author{
Ghulam Nurul Huda*)1, Bonar M Sinaga ${ }^{* *}$, and Trias Andati***) \\ *) PT Hasnur Citra Terpadu \\ Jl. Jendral Sudirman Kav.52-53, DKI Jakarta 12110 \\ ${ }^{* *}$ Department of Economic, Faculty of Economics and Management, Bogor Agricultural University \\ Jl. Kamper, Wing 4 Level 5, Campus of IPB Darmaga Bogor 16680 \\ ${ }^{* * *}$ PT Adhimix Precast Indonesia \\ JL. Raya Pasar Minggu, No. 17 A, Pancoran, Jakarta, 12780
}

\begin{abstract}
This study was conducted to examine the effect of financial performances of Economic Value Added (EVA), Market Value Added (MVA) as well as financial ratios (Fixed Asset Turnover, Return on Investment, Debt to Equity Ratio, Price to Book Value, Total Asset Turnover) on Stock Return. This study used the data of six representative palm oil companies which were listed in Indonesia Stock Exchange. The analysis models that were used included three multiple regression equations for EVA, MVA and Stock Return. The results indicate that DER significantly influences EVA and PBV, and TATO significantly influences MVA. Return Shares are significantly only affected by EVA. The company's fundamentals, especially EVA, $P B V$, TATO and DER were used by investors to predict the Stock Return in Indonesia Stock Exchange in 2009-2014 period. This study confirmed the previous studies that these variables are involved on regression model to predict the Stock Return. The results of the analysis of the company's financial performance with EVA and MVA and financial fundamental variables provide a better alternative picture on the achievement of the company so that the benefits in investing in the palm oil business in Indonesia can be maximally managed.
\end{abstract}

Keywords: Indonesia Stock Exchange, investor, market, multiple regression, stock

\begin{abstract}
ABSTRAK
Penelitian ini dilakukan untuk menguji pengaruh kinerja keuangan Economic Value Added (EVA) dan Market Value Added (MVA), serta rasio keuangan (Fixed Asset Turnover, Return on Investment, Debt to Equity Ratio, Price to Book Value, Total Aset Turnover) terhadap Return Saham. Penelitian ini menggunakan enam sampel perusahaan produsen minyak sawit yang terdaftar di Bursa Efek Indonesia. Model analisis yang digunakan adalah tiga persamaan regresi berganda untuk EVA, MVA dan Return Saham. Hasil penelitian menunjukkan bahwa DER berpengaruh signifikan terhadap EVA. PBV dan TATO berpengaruh signifikan terhadap MVA. Return Saham hanya dipengaruhi secara signifikan oleh EVA. Faktor fundamental perusahaan terutama EVA, PBV, TATO dan DER digunakan oleh investor untuk memprediksi Return Saham di Bursa Efek Indonesia pada periode 2009-2014. Penelitian ini mempertegas hasil penelitian sebelumnya yang menyebutkan variabel EVA, PBV, TATO dan DER ke dalam model regresi untuk memprediksi Return Saham. Hasil analisis kinerja keuangan perusahaan dengan EVA, MVA, dan Variabel fundamental keuangan memberikan alternatif gambaran yang lebih baik atas pencapaian yang dilakukan perusahaan sehingga keuntungan yang diperoleh didalam melakukan investasi pada bisnis kelapa sawit di Indonesia dapat dikelola dengan maksimal.
\end{abstract}

Kata kunci: bursa efek Indonesia, investor, pasar, regresi berganda, saham

\footnotetext{
${ }^{1}$ Corresponding author:

Email: ghulamnurulhuda@gmail.com
} 


\section{INTRODUCTION}

In general, the analysis of financial statements using the conventional method of financial ratio analysis is used by the company to measure its financial performance. In practice, even though financial ratio analysis used has sufficient functionality and usability for the company to make decisions, it does not mean that the financial ratio can guarantee its real financial condition and position for $100 \%$ (Kashmir, 2010). The use of financial ratio analysis has a major weakness; it does not pay attention to the risks faced by the company at the expense of their cost of capital. One way to overcome the weaknesses of financial ratio analysis is by developing the concept of measuring financial performance based on value added), namely, economic value added (EVA) and Market Value Added (MVA). According to Winarto (2005), both methods of added values can be used as a better reference for owners of capital to consider whether the company will provide gains or cause losses on invested capital.

Based on the strategic data issued by the Central Statistics Agency (BPS) in 2013, the value of Gross Domestic Product (GDP) of Indonesia on the basis of a constant price of 2.000 in 2013 amounted to IDR $2.770,3$ trillion, increasing up to IDR151,4 trillion, compared to that in 2012 (IDR2.618, 9 trillion). When viewed by the applicable price, GDP in 2013 increased by IDR854,6 trillion i.e. from IDR8.229, 4 trillion in 2012 to IDR9.084,0 trillion in 2013. The agricultural and the plantation sectors were among the largest contributors to GDP with a total value of IDR 1.047,4 billion or $37,8 \%$ or increased by $3,5 \%$ from the previous year.

From the distribution of agricultural and plantation sectors in Indonesia, the commodities of Crude Palm Oil (CPO) play a significant role and show a positive growth trend and a promising business expansion. In 2013, trade balance of CPO and its derivatives gave the largest contribution of agriculture and plantations amounted to US\$20,52 billion. The average rate of growth of oil palm area from 2004-2012 was amounted to $7,14 \%$, while the production of palm oil increased by $10,97 \%$ per year. In 2012, the total area was estimated to reach 9,07 million hectares with the production of 23,52 million tons. The export realization of oil palm commodity until 2012 had reached a volume of 20,57 million tons (palm oil/CPO and other palm oil) with a value of US\$ 19,35 billion (Agricultural Development Performance in 2004-2013, the Ministry of Agriculture).

The selection of issuers that could provide optimum return rate for the investors required a good, actual and accurate judgment. Investors must select investments that would increase the economic value and market value on the investment decision issued. The use of EVA and MVA methods in analyzing the company's performance is expected to provide an alternative of better picture on the achievement of the company, especially in this case, the company producers of palm oil. Therefore, the effect of the financial performance of companies on share returns is important for investors in analyzing the company performance.

\section{METHODS}

Data collected in the study were secondary data, both quantitative and qualitative, i.e. quarterly financial statements and other supporting literature. The data were obtained from Indonesian Share Exchange, the internet, the Executive Capital Market Agency, and monthly reports of BI (Bank of Indonesia).

This research was a case study with a descriptive approach. In this study, six companies of palm oil producer listed in Indonesia Share Exchange were chosen. The companies obtaining the highest EV/ EBITDA in the third quarter of 2014 based on the IFT Research Department in reference to JP Morgan included PT PP London Sumatra Tbk, PT Tunas Lampung Baru Lampung Tbk, PT Astra Agro Lestari Tbk, PT BW Plantation Tbk, and PT Sampoerna Agro Tbk. The data were analyzed using regression.

\section{Dependent Variable (Shares Return)}

The period referred to in this study was an average month in the period of 2009-2014. Share Return was calculated by the following formula:

$$
\mathrm{Pa}_{\mathrm{i}}=\left(\mathrm{P}_{\mathrm{i} . \mathrm{t}}-\mathrm{P}_{\mathrm{i} . \mathrm{t}-1}\right) / \mathrm{P}_{\mathrm{i} . \mathrm{t}-1}
$$

In which:

$\mathrm{P}_{\text {it }}=$ price of share $\mathrm{I}$ in quarter $\mathrm{t}$

$\mathrm{P}_{\mathrm{it}-1}=$ price of share in quarter $\mathrm{t}-1$ 


\section{Independent Variables}

\section{Calculation of EVA}

EVA calculation by G. Bennett Stewart III (1991) is formulated as follows:

$$
\mathrm{EVA}=\mathrm{NOPAT}-\mathrm{COC}
$$

In which:

$$
\begin{array}{ll}
\text { NOPAT } & =\text { Net Profit }+ \text { Interest Expense }- \text { Tax } \\
\text { COC } & =\text { Invested Capital } \mathrm{x} \text { WACC }
\end{array}
$$

\section{Calculation of MVA}

MVA, according to Stern Stewart (1996) is a "cash difference either debt or equity the investors have in the company and contributes to the expected cash value" and is formulated as follows:

MVA = Equity Market Value - Equity Book Value

In which:

$$
\begin{aligned}
\mathrm{EMV}= & \text { Number of shares } \mathrm{x} \text { Price/Shares } \\
\mathrm{EBV}= & \text { Number of shares } \mathrm{x} \text { Nominal value/ } \\
& \text { Shares }
\end{aligned}
$$

\section{Fixed Assets Turnover (FATO)}

FATO indicates how effective the management is in the use of every dollar of sales of fixed assets (Keown, 2000). FATO calculation formula is as follows:

$$
\begin{aligned}
& \text { ROI }=\frac{\text { profit after tax }}{\text { Total assets }} \\
& \text { FATO }=\frac{\text { sales }}{\text { fixed assets }}
\end{aligned}
$$

\section{Return on investment (ROI)}

ROI is the most important ratio among the other profitability ratios when used to predict the share return. (Ang, 1997). ROI is the ratio between profit after tax and total assets in the same period. Formulation of ROI calculation is as follows:

$$
\text { ROI }=\frac{\text { Profit after tax }}{\text { Total assets }}
$$

\section{Debt to Equity Ratio (DER)}

Debt to Equity Ratio (DER) is a group solvency ratio used in this study. Debt to Equity Ratio is a ratio that compares the amount of debt to equity of the company (Keown, 2000). Formulation of DER calculation is as follows:

$$
\text { DER }=\frac{\text { Total debt }}{\text { Total equity }}
$$

\section{Price to Book Value (PBV)}

Price to Book Value ratio is one market ratio that can be used to measure performance against the share market price book value (Keown, 2000). PBV calculation uses the following formulation:

$$
P B V=\frac{\text { Ps }}{\mathrm{BVS}}
$$

in which:

$$
\begin{aligned}
& \text { Ps }=\text { Price (share price) } \\
& \mathrm{BVS}=\text { Book Value (book value) }
\end{aligned}
$$

\section{Total Assets Turnover (TATO)}

TATO is one activity ratio and is measured by:

$$
\text { TAT0 }=\frac{\text { Sales }}{\text { Total assets }}
$$

\section{Regression Analysis}

Analysis model used in this study was multiple regression analysis with the variables of FATO of $\left(\mathrm{X}_{1}\right)$, ROI of $\left(\mathrm{X}_{2}\right)$, DER $\left(\mathrm{X}_{3}\right)$, TATO of $\left(\mathrm{X}_{4}\right)$, PBV of $\left(\mathrm{X}_{5}\right)$, EVA of $\left(X_{6}\right)$, dan MVA of $\left(X_{7}\right)$, share return of $(Y)$.

$$
\begin{aligned}
& \text { EVA }_{i t}=a_{0}+a_{1} X_{1 i t}+a_{2} X_{2 i t}+a_{3} X_{3 i t}+U_{1 i t} \\
& \text { MVA }_{i t}=b_{0}+b_{1} X_{4 i t}+b_{2} X_{5 i t}+U_{2 i t} \\
& \text { Ret }_{\text {it }}=c_{0}+c_{1} X_{6 i t}+c_{2} X_{7 i t}+U_{3 i t}
\end{aligned}
$$

in which:
$(\mathrm{Y})=$ Share Return $(\%)$
$\left(\mathrm{X}_{1}\right) \quad=$ Fixed Asset Turnover
$\left(\mathrm{X}_{2}\right) \quad=$ Return on Investment $(\%)$
$\left(\mathrm{X}_{3}\right)=$ Debt Equity Ratio
$\left(\mathrm{X}_{4}\right)=$ Total Asset Turnover
$\left(\mathrm{X}_{5}\right)=$ Price to Book Value
$\left(\mathrm{X}_{6}\right)=$ Economic Value Added (USD)
$\left(\mathrm{X}_{7}\right)=$ Market Value Added (USD)
$\mathrm{a}, \mathrm{b}, \mathrm{c}=$ coefficient of regression of each variable
$\mathrm{U}=$ disturbance error
$\mathrm{i}=$ oil palm plantation company data observed
$\mathrm{t}=$ time series data showing the length of time taken 
Based on the formulation of the problem and the scope of the study, the following theoretical framework was presented as outlined in the research model as shown in Figure 1 used as a basis to formulate hypotheses. The hypotheses in this study were as follows:

H1: Fixed Asset Turn Over has a positive effect on share returns

$\mathrm{H} 2$ : Return on investment has a positive effect on share returns

H3: Debt to Equity Ratio has a negative effect on share returns

H4: Total Assets Turnover has a positive effect on share returns

H5: Price to Book Value has a positive effect on share returns

H6: Economic Value Added has a positive effect on share returns

H7: Market Value Added has a positive effect on share returns

\section{RESULTS}

\section{Descriptive Analysis}

Indonesia has a competitive advantage in the palm oil industry because it is supported by natural resources, in the form of large tracts of land distribution and tropical climate which are ideal to oil palm tree growth. Based on the data of Ministry of Agriculture, Indonesia is currently the largest producer and exporter of palm oil in the world with $44,5 \%$ dominating the world oil market (in 2013) followed by Malaysia (41,3\%), Thailand (2,7\%), Nigeria (2\%) and Colombia (1,9\%).

In 2014, based on predictions of the Indonesian Palm Oil Association (GAPKI), the total production would rise by $6,4 \%$ to 25 million tons, equal to IDR 225 trillion at a price of US\$ $1.000 /$ ton. Of the total production, the export volume of crude oil or Indonesian $\mathrm{CPO}$ and its derivative products would reach 19,5 to 21 million tones, increased from the total export in 2013 from 1,5 to 2 million tons.

\section{Financial Performance Analysis}

The financial performance of the company may be based on aspects of added value (Value added), i.e. economic value added (EVA) and Market Value Added (MVA). Based on the research results by Panigrahi, (2014) both calculations of this added value can be used as a better reference for owners of capital to consider the cost of capital to generate profits.

\section{EVA Calculation Results}

The development of EVA of oil palm producers in the period of 2009-2014 seemed to be able to create an additional economic value as can be seen in Figure 2. Based on the graph of the development of EVA of palm oil producer in the period 2009-2014, they have been able to create an additional economic value. One of the main factors in the creation of economic value added is the high value of the adjusted NOPAT (NOPAT and EVA calculation) of the company accompanied by higher CPO sales and a decline in operating expenses of the company. On the average, the company recorded positive EVA issuers over the period 2009-2014. From the six companies listed as oil palm plantation companies, PT Tunas Baru Lampung Tbk was the highest economic value creator with an average EVA creation of IDR622.084 million dollars annually. The lowest of EVA value creation was obtained by PT Sampoerna Agro Tbk amounting to IDR142.737 million.

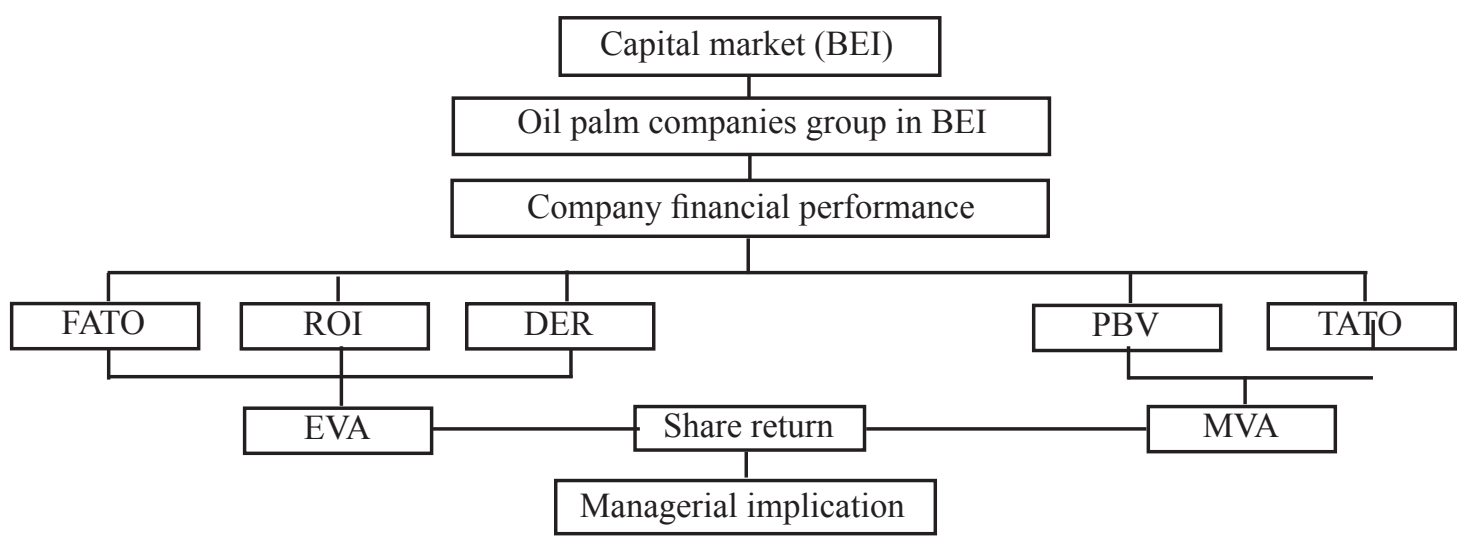

Figure 1. Research Framework 
PT Tunas Baru Lampung Tbk became the most dominant issuer in the creation of EVA due to the company's success in increasing sales by $30-40 \%$, so that the company's net profit after tax was high. In addition, the burden of the company's operations could be suppressed. Thus, the EVA value would be higher.

\section{Calculation of MVA results}

MVA calculation results of the listed palm oil producers for the period 2009-2014 had succeeded in creating an additional value for the market. The calculation result can be seen in graph form in Figure 3 MVA development.

Based on the graph of the MVA development of the palm oil producer issuers in the period of 2009-2014, it can be seen that they had already succeeded in creating an additional value for the market. Companies that have a positive MVA tend to produce a positive share return. This is in response to the performance of share market companies that has a market value of equity higher than the book value.
Based on the results of MVA comparison of the 6 issuers of oil producers, it can be seem that PT Astra Agro Lestari had a higher MVA value when compared to other issuers whose annual average was IDR30,7 trillion. This figure shows that the market response to the company's share performance is good, while the smallest MVA of the six companies was obtained by PT Tunas Baru Lampung with an annual average of MVA value of IDR 1,07 trillion.

\section{The Effect of Financial Performance return on Shares}

\section{Descriptive data}

Based on the raw data obtained from Indonesia Share Exchange (ISE), the financial ratios used in this study could be calculated. Furthermore, the average value (mean) and standard deviation $(\delta)$ of each of the variables can be seen in Table 1.

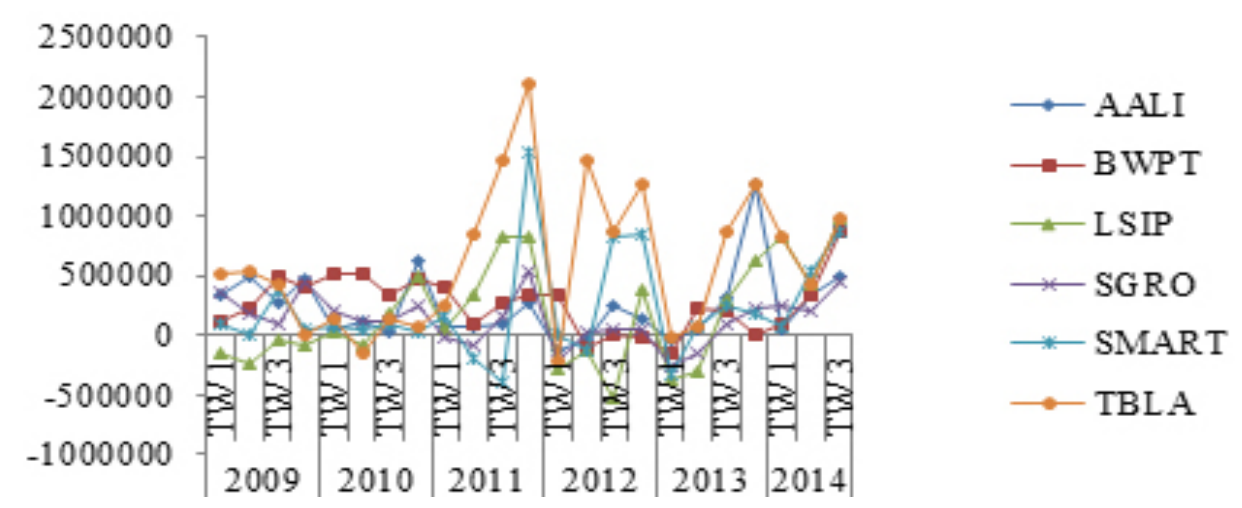

Figure 2. Graph calculation of EVA of 6 issuers of oil manufacturer (company's quarterly financial statements, processed

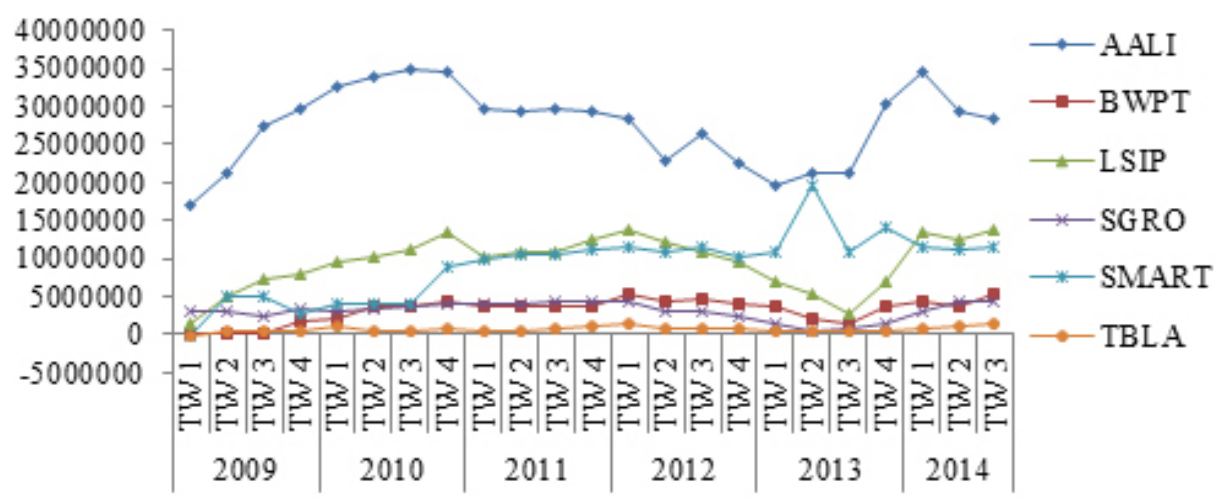

Figure 3. Graph of the result of MVA calculation on the 6 issuers of oil manufacturers (company's quarterly financial statements, processed 
Table 1. Descriptive statistics

\begin{tabular}{lccc}
\hline & Mean & Std. deviation & $\mathrm{N}$ \\
\hline RETURN & 0,0169 & 0,100158 & 138 \\
EVA & 276107 & 421540,1109 & 138 \\
MVA & 883581 & 9543243,801 & 138 \\
CR & 3,0249 & 1,751395 & 138 \\
ROI & 0,1265 & 0,101050 & 138 \\
DER & 0,5257 & 0,626479 & 138 \\
TATO & 0,5489 & 0,761460 & 138 \\
PBV & 2,7694 & 1,150804 & 138 \\
\hline
\end{tabular}

Source: Secondary Data, 2014 BEI processed

Based on the results of the calculations in Table 1 , it appeared that from the 6 companies with 138 observations, the average share return during the observation period (2001-2003) was 0,01699 with a standard deviation (SD) of 0.100158 .

\section{Data normality}

This classic assumption data test is to determine the normality of the data by using the Kolmogorov-Smirnov test showing significances of 0,$000 ; 0,000,0,000$, $0,0084,0,019,0,000,0,000$ and 0,007 . Since there were seven variables that were not normally distributed, the technique to normalize the distribution of the data was performed in the form of transform-Ln as follows: Ln.Return $(0,17)$, Ln.EVA $(0,114)$, Ln.MVA $(0,122)$ Ln.FATO (0,231), Ln.ROI $(0,192)$; Ln.DER $(0,061)$, Ln.TATO $(0,122)$, and Ln.PBV $(0,213)$. This indicates that the independent variables used in this study could be used to predict the Share Return oil palm companies listed in the Share Exchange 2009-2014.

\section{Multicollinearity test results}

Multicollinearity Test results of VIF calculation shows that multicollinearity did not occur in the seven independent variables because the VIF value was $<5,00$. Thus, the seven independent variables (EVA, MVA, CR, ROI, DER, TATO, and PBV) could be used to predict share returns during the observation period.

\section{Heteroskidastity}

Glejser test shows no significant results; therefore, it could be concluded that in all independent variables, the heteroskidastity did not occur in the error variance.

\section{Autocorrelation test results}

Regression results show the level of significance of 0:05 $(\alpha=0,05)$, with a number of independent variables $(\mathrm{k}$ $=5)$ and the number of data $(\mathrm{n}=29)$. Result of Durbin Watson calculation was 1,998; whereas in the DW table for "k" $=5$ and $\mathrm{N}=132$, the amount of DW-table of $\mathrm{dl}$ (outer boundary) $=1,52$; of du (limits in) $=1,77$; $4-\mathrm{du}=2,23$; and $4-\mathrm{dl}=2,486$, therefore, it could be concluded that the calculation of DW-test was located in the test area.

\section{Regression Analysis}

Results of testing of the hypotheses could explain the following:

\section{Financial performance with EVA}

EVA equation is the model used in this study to test the effect of independent variable on Ln FATO, ROI Ln, Ln Der to Ln EVA with a level of $\alpha=0,10$ or $10 \%$ as shown in Table 2. Based on the estimation equation of Economic Value Added (EVA), it was found that DER significantly affected the EVA. The regression coefficient of $-0,255 \times 3$ implied that each addition of $1 \%$ of DER would reduce the EVA by $0,255 \%$.

The estimation result in the calculation was in accordance with the research of James and Shimin (1996) and Natarsyah (2000). The results of this study indicate that the level of leverage of the company becomes the management performance appraisals so that DER becomes the concern of the investors in making investment decisions.

Table 2. Regression analysis of equation I

\begin{tabular}{lccc}
\hline \multicolumn{1}{c}{ Model } & Coef & T & Sig. \\
\hline (Constant) & 12,02 & 34,55 & 0,00 \\
LNFATO & 0,009 & 0,08 & 0,93 \\
LNROI & 0,073 & 0,56 & 0,57 \\
LNDER & $-0,255$ & $-2,64$ & 0,01 \\
F & 2,447 & & \\
Sig. F & 0,068 & & \\
R2 & 0,066 & & \\
Adj. R2 & 0,039 & & \\
\hline
\end{tabular}


In the first hypothesis, it shows that Fixed Asset Turnover has a significantly positive effect on share returns. The results of this study could be concluded that the higher the company FATO, the lesser risk of failure of the company to meet its short term obligations.

In the second hypothesis, it shows that ROI has a significant influence on share returns. The positive sign of ROI in this study concludes that the higher the ROI of a company, the more it affects the increase in its value of share returns.

In the third hypothesis, it indicates that DER has a significantly negative effect on share returns. The higher the value of DER, the more it reduces the increase of the company's share.

\section{The financial performance with MVA}

The financial performance with MVA equations is the model used in this study to test the effect of independent variables, namely, Ln DER, Ln PBV to Ln MVA with a level of $\alpha=0,10$ or $10 \%$ as can be seen in Table 3 . From the estimation results of regression analysis, it shows that TATO and PBV significantly affect MVA. Regression coefficient of $0,281 \mathrm{X}_{4}$ states that each addition of $1 \%$ of TATO will increase MVA by $0,281 \%$. Regression coefficient of $0,226 \mathrm{X}_{5}$ states that any addition of $1 \%$ of PBV will increase MVA by $0,226 \%$.

The estimation results in the calculation was in accordance with the research by Subekti (2006) and Tuasikal (2002) who stated that there was a significant relationship between TATO and PBV, and they were directly influential to MVA. This is because TATO and PBV indicate the company's success in affecting the sales of assets in activities that cause investors interested in investing in the long-term investments.

The fourth hypothesis indicates that TATO has a significantly positive effect on share returns. TATO high value describes the influential degree of the increase of shares sales. The fifth hypothesis indicates that PBV has a significantly positive effect on share returns. High PBV values will increase the price of the stocks and guarantee for the investors in investing their funds.

\section{Relations of EVA, MVA with share return}

Share return equation is the model used in this study to test the effect of independent variables of Ln EVA and Ln MVA and the control variable of Ln Return. This equation used the level of $\alpha=0,10$ or $10 \%$ as can be seen in Table 4. Based on the estimation results of regression analysis, it was found that EVA significantly affects the Share Return. Regression coefficient of $0,132 \mathrm{X}_{6}$ states that each addition of $1 \%$ EVA will increase the share return of $0,132 \%$.

The estimation results in the calculation were in accordance with the same study of EVA conducted by Bacidore et al. (1997) that stated that EVA has a significant influence on return shares. This is because investors consider the economic aspects to see the ability of the company in creating added value.

The sixth hypothesis shows that EVA has a significantly positive effect on share returns. The result of this study concludes that higher EVA of a company means that the company is able to create added economic value which then affects the increase in the value of share returns, as well as the return on investment in shares.

Table 3. Regression analysis of equation II

\begin{tabular}{lccc}
\hline \multicolumn{1}{c}{ Model } & Coef & T & Sig. \\
\hline (Constant) & 13,543 & 63,80 & 0,00 \\
LNTATO & 0,281 & 4,05 & 0,00 \\
LNPBV & 2,279 & 12,10 & 0,00 \\
F & 84,481 & $-2,64$ & 0,01 \\
Sig. F & 0,000 & & \\
R2 & 0,565 & & \\
Adj. R2 & 0,558 & & \\
Adj. R2 & 0,039 & & \\
\hline
\end{tabular}

Table 3. Regression analysis of equation III

\begin{tabular}{lccc}
\hline Model & Coef & T & Sig. \\
\hline (Constant) & $-5,99$ & $-4,07$ & 0,00 \\
LNEVA & 0,13 & 1,86 & 0,06 \\
LNMVA & 0,07 & 1,15 & 0,24 \\
F & 2,09 & & \\
Sig. F & 0,12 & & \\
R2 & 0,06 & & \\
Adj. R2 & 0,03 & & \\
\hline
\end{tabular}


The seventh hypothesis shows that MVA has a significantly positive effect on share returns. The result of this study concludes that higher MVA of a company will affect the increase in the value of share returns. In other words, the change of company MVA shows good capital market ratings.

Kumianny et al. (2002) state that the independent variables have a significant effect on the dependent variable. The research conducted by Sunardi (2010) also stated that EVA and MVA become a benchmark of financial performance in generating profits from palm oil business in Indonesia.

\section{Managerial Implications}

The managerial implications of the study results will provide views to investors to consider the information issued by the company, and such information includes EVA, MVA, and DER because this information is influential the share returns and help investors to take the right decision in investing the shares on the Stock Exchange. Besides, the investors should also consider other factors beyond the company's policy, market conditions and external factors because they will indirectly affect profits in investment.

\section{CONCLUSIONS AND RECOMMENDATIONS}

\section{Conclusion}

Based on the results of the discussion, it can be concluded that: 1) Financial performances of the six oil companies in Indonesia have been reasonably good. Both values of EVA and MVA are positive, indicating that the companies are able to create an added value for the market and economy. 2) Results of regressions of EVA and MVA on share returns state that EVA partially significantly affects the share return of palm plantation sector companies that "go public" in BEI, while MVA does not significantly affect the share return. This is because the palm plantation sector has a rapid payback period as a result of its initial outlay to be borne and the costs to undergo any major business activity. Thus, the cost of capital is smaller than the company's earnings (it does not produce any value added). 3) The estimation results in the regression equations obtain that the EVA equation shows significant changes of DER variables which affect the EVA. In the equation of MVA, TATO and PBV variables significantly influence the MVA. On shares Return equation, EVA variable significantly affects the Share Return.

\section{Recommendations}

Based on the conclusion, there are some suggestions that can be useful for other parties: For investors, they should pay attention not only to the fundamental factors in investing in the share market but also to the economic condition of the company.

The rates of shares return are affected by EVA and MVA as a measure of a company's financial performance. Therefore, to obtain adequate investors with high share returns, the company needs to improve the financial performance, especially its EVA and MVA by considering the cost of capital because it becomes a consideration in maximizing the value of the company and in taking the right decision to invest.

For further similar researches, the research should be conducted by adding a measure of financial performance other than EVA, MVA and Systematic Risk. The researches are conducted not only in the company of plantation sector, and they also should pay attention to the size of the company.

\section{REFERENCES}

Bacidore JM, Boquist JA, Milbourn TT, Thakor AV. 1997. The search for the best financial performance measure. Financial Analysts Journal 3(2): 53. http://dx.doi.org/10.2469/faj. v53.n3.2081.

James LD, Shimin C. 1996. Economic value added and market value added. Journal Economic and Management 30(4):1-8.

Kasmir. 2010. Introduction to Financial Management. First Edition. Jakarta: Kencana Prenada media group.

Kumiany A. Saputra, Elly, and Pwee Leng. 2002. Effect of Systematic Risk and Liquidity Against Stock Return Bodies Go Public Enterprises in the Jakarta Stock Exchange in 1999. The Journal of Management and Entrepreneurship 4 (1): 1525. 
Kurniadi A. 2013. Financial performance-based value creation, macroeconomic factors and its effect on stock return agricultural sector. Journal of Accounting and Finance 15(2): 11-15.

Natarsyah S. 2000. Effects of multiple factor analysis fundamentals and systematic risk on the stock market: the case of the consumer goods industry go public in Indonesia capital market, Journal of Economics and Business 15(3): 294-312.

Panigrahi S. 2014. Investigating relationship between EVA and MVA of selected construction companies in Malaysia. The International Journal of Business and Management 4(4): 280-289.
Stern S and Co. 1996. The Stern Stewart Performance 1000, The Definitive Guide To MVA and EVA. Munich: Stern Stewart Management Service.

Subekti PA 2006. Analysis of Fundamental Factors, Eva, and Mva Against Stock Return. Semarang: Diponegoro University.

Sunardi H. 2010. Effects of performance assessment by ROI and EVA to return shares in the company incorporated in LQ 45 index in Indonesia stock exchange. Journal of Accounting 2(3): 70-92. 